Vol. I No. 2 - August 2020

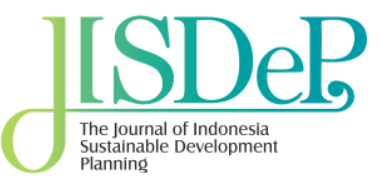

E-ISSN: 2722-0842 | P-ISSN: $\underline{\text { 7721-8309 }}$

Available online at

http://journal.pusbindiklatren.bappenas.go.id/

\title{
A Review of Suramadu Regional Development Acceleration towards Sustainable Development Concept
}

\author{
Agus Manshur ${ }^{1}$ and Firre An Suprapto ${ }^{2}$ \\ Ministry of National Development Planning, Jakarta, Indonesia ${ }^{1}$; \\ Bogor Agricultural Institute, Bogor, Indonesia ${ }^{2}$ \\ manshursky@gmail.com; supraptofirre@apps.ipb.ac.id
}

\begin{abstract}
Based on the Surabaya Madura Regional Development Agency Master Plan 2010-2024, Madura Island has a strategic position as part of the Gerbangkertosusila Urban National Strategy. There is still, however, a development disparity between Madura Island and East Java. This can be seen from the economic performance of Madura Island which is quite low compared to other districts or cities in East Java Province. Madura Human Development Index (HDI) is below the East Java on average, and the percentage of poor people in Madura is the highest in East Java. Therefore, the development of SurabayaMadura (Suramadu) must be integrated through regional development, such as development of connectivity systems. The research used descriptive analysis to assess the characteristics of a program and to adjust the characteristics with sustainable development theory that consists of three components, namely: environmental, economic, and social developments. These can ultimately be used to sharpen the development target to be achieved in the next 5 (five) years. Data were collected using secondary survey instruments through existing literature studies and policy reviews, such as National Medium-Term Development Plan 2020-2024 and Regional Medium-Term Development Plan of East Java Province.
\end{abstract}

Keywords: Suramadu Region, Sustainable Development, Descriptive Analysis

\begin{tabular}{|c|c|c|}
\hline ARTICLE INFO & $\begin{array}{l}\text { JISDeP - The Journal of Indonesia } \\
\text { Sustainable Development Planning }\end{array}$ & $\begin{array}{l}\text { Address: Jalan Proklamasi 70, } \\
\text { Central Jakarta, Indonesia } 10320\end{array}$ \\
\hline Received: June 23, 2020 & Published by Centre for Planners' & Phone: +62 $2131928280 / 3192828$ \\
\hline Received in revised form: July 24, 2020 & Development, Education, and Training & Fax: +62 2131928281 \\
\hline Accepted: August 3, 2020 & $\begin{array}{l}\text { (Pusbindiklatren), } \\
\text { Ministry of National Development }\end{array}$ & E-mail: pusbindiklatren@bappenas.go.id \\
\hline $\begin{array}{l}\text { doi: } 10.46456 / \mathrm{jisdep} . \mathrm{v} 1 \mathrm{i} 2.72 \\
\text { (C) } 2020 \text { The Author }\end{array}$ & $\begin{array}{l}\text { Planning/ National Development } \\
\text { Planning Agency (Bappenas), Republic } \\
\text { of Indonesia }\end{array}$ & $\begin{array}{l}\text { Supported by Indonesian Development Planners } \\
\text { Association (PPPI) }\end{array}$ \\
\hline
\end{tabular}




\section{Introduction}

National development is an effort to utilize all components of the nation to achieve the goal of the formation of the Unitary State of the Republic of Indonesia. To achieve this development goal, planning activities are carried out through long-term, medium-term, and annual planning policies implemented in stages. Madura Island is an inseparable region of East Java Province with a large economic potential which attracts attention for investors. This potential has been indeed outlined in the Suramadu Region development plan which is inseparable from the development of the East Java Region as stipulated in Regional Medium-Term Development Plan (Rencana Pembangunan Jangka Menengah Daerah-RPJMD) of East Java Province to improve the economy and the welfare of the community at large.

The development plan of Surabaya-Madura region after the construction of the Suramadu Bridge is in line with the establishment of institutions that have the authority and responsibility in developing the Surabaya-Madura region, namely the Suramadu Regional Development Agency as outlined in Presidential Regulation Number 27/2008 on the Surabaya-Madura Regional Development Agency. Surabaya-Madura Regional Development Agency consists of a Steering Board and an Implementing Agency tasked with preparing the Master Plan and plan activities for the development of facilities and infrastructure as well as the development activities of the Suramadu area. Surabaya-Madura Regional Development Agency is also tasked with synchronizing the policies of the Central Government and Regional Governments relating to the development of the Suramadu region.

Through the development concept contained in the Master Plan for the Acceleration of Suramadu Regional Development, it is expected that development weaknesses that occur in the Suramadu region do not cause development disparity between regions, which is caused by the uneven distribution of human and natural resources due to infrastructure limitations. Development disparity between regions in East Java Province does not only occur between the North Coast and South Coast areas of East Java, but this condition also occurs between Madura Island and East Java. This can be seen from the economic performance of Madura Island which is quite low compared to other regencies/cities in East Java Province. Retrieved from the 2019 statistical data, economic growth in Madura was $0.14-1.42 \%$ below the East Java on average (5.52\%), except Pamekasan Regency. In fact, the target of economic growth in Madura until 2024 is expected to be close to the economic growth of East Java Province, i.e. 6.0-6.5\%. Another indicator is that the Madura Human Development Index (HDI) of 61.94-66.22 is also below the East Java on average (71.50). Furthermore, the percentage of poor people in Madura is the highest in East Java, where Sampang Regency is ranked first at $20.71 \%$ then followed by Sumenep Regency at $19.48 \%$.

Conceptually, the development of Madura Island needs to be integrated with the development of the City of Surabaya and its surroundings to encourage economic development in the Madura Island and to reduce the bias of urban investment in the City of Surabaya and its surroundings. Therefore, the development of Surabaya-Madura (Suramadu) must be integrated through regional development (industry, warehousing, trade in services, tourism, public facilities and settlements), development of connectivity systems through infrastructure support, human resource development, and develop ment of leading economic clusters based on the local economy to become a major necessity.

So far, the development of the Suramadu region through the acceleration development program of the Suramadu Region has been compiled and implemented by integrating the central, sector (transportation, public works, marine and fisheries, agriculture, and tourism and creative economy) and regional (provincial and district/city) policies. At this point, the implementation of the development of the Suramadu region is guided by the Master Plan for the Acceleration of the Development of Suramadu Region (RIP2WS) as a general policy and implementation guide for BPWS, sectors, and regions. This is to integrate the medium-term program and harmonization of the annual program into the implementation of the accelerated development program of the Suramadu Region through coordinating with the East Java Provincial Government together with the BPWS Implementing Agency.

In addition, the implementation of development refers to strategic planning in 2015-2019. The development in Suramadu Region is increasingly complex and there are many changes in the strategic environment. Therefore, it needs to sharpen and adjust the direction of development both to accommodate the needs of new initiatives that have not been listed in the Master Plan and to accelerate The Development of Suramadu Region or Agency Medium Term Strategic Plan of 2020-2024 and synergy 
with the National Medium-Term Development Plan of 2020-2024. In addition, the direction of development has been done as a form of harmony in the Agency Medium-Term Strategic Plan of 20202024 with the concept of sustainable development, realizing regional development oriented to economic development by taking into account the sustainability of natural/environmental resources and social development.

Sustainable development is a development that satisfies current needs without reducing the ability of the future generation to supply their own needs (Silva et al., 2020). Sustainable development is a social construction with decision-making rules based on values related to current and future development, which must be understood in the context of a dynamic environment, inseparable from society (He et al., 2019). This means that there is a need for optimization between the achievement of economic goals (growth and efficiency), social goals (equity, participation, and harmony), and the environment such as carrying capacity and biodiversity (Szopik-Depczyńska et al., 2018). Minimizing the impact of economic growth on the environment often results in disrupted environmental conditions and ecosystems (Kroll \& Zipperer, 2020). Therefore, regional economic growth needs to be harmonized with the need to conserve the environment (Heidenreich, 2003). Given the attraction of interests that are not always in line, effective government intervention is needed to realize optimal sustainable development (Munda \& Saisana, 2011).

To respond these challenges, the Roadmap for Suramadu Regional Development Acceleration to Increase Community Welfare will be carried out through the development of integrated and sustainable local potential in realizing National Priorities in the RPJMN 2020-2024. As a result, the implementation is necessary to consider the concept of sustainable development which can ultimately be used to sharpen the development target to be achieved in the next 5 (five) years.

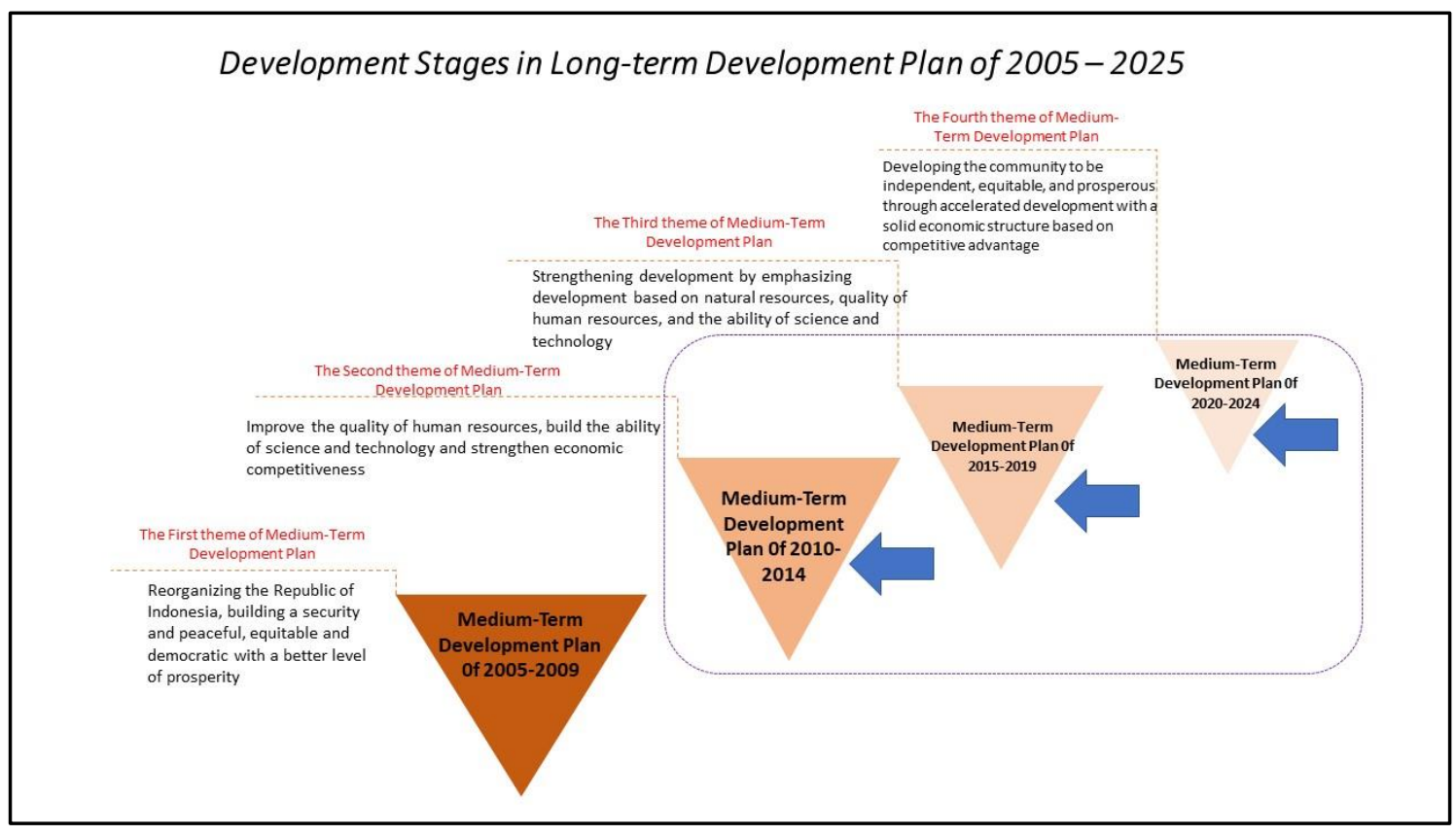

Figure 1. Development Stages in Long-term Development Plan of $2005-2025$

The preparation of this road map is intended to provide inputs related to the direction of the development of the Suramadu Region in the upcoming national priorities to be in line with the MediumTerm Development Plan of 2020-2024. The research method used the descriptive analysis by explaining the suitability of policy directives with the theory of sustainable development. 


\section{Methodology}

The research method of this case study used descriptive analysis specifically using the analysis of conformity with the concept of sustainable development. Descriptive analysis was conducted by assessing the characteristics of a program and adapted to the characteristics of the sustainable development theory consisting of three components, namely: environmental development, economic development, and social development. The research sites were in Suramadu Area consisting of (1) foot area of Surabaya-Madura bridge covering the area on the Surabaya side about 600 hectares and the area on the side of Madura around 600 hectares, and (2) Specific area in Madura Island covering approximately 600 hectares in a single unit with a container port area with housing and industry including its access road. The research sites are shown in Figure 2.

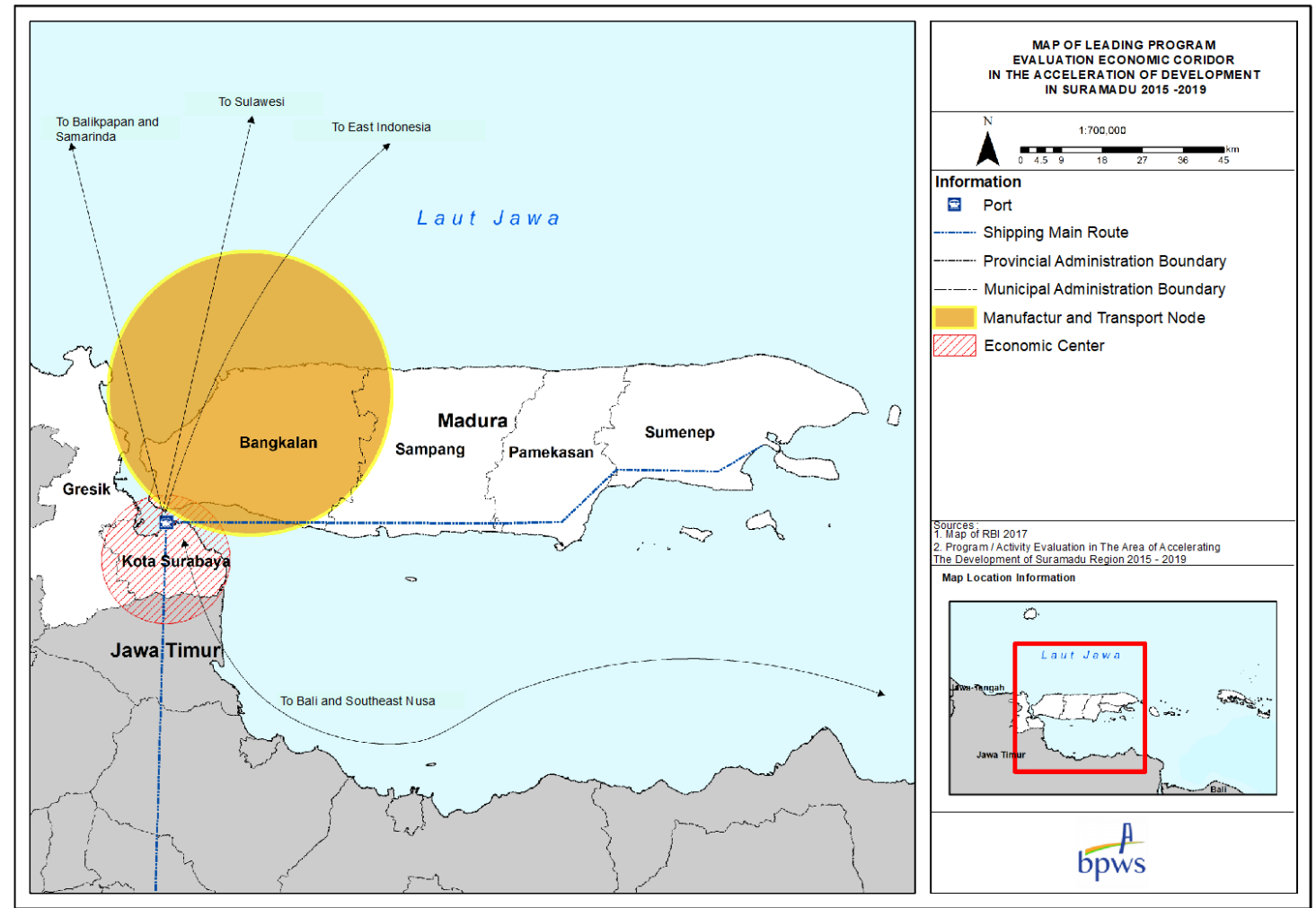

Figure 2. Suramadu area seen from the Java Economic Corridor, Masterplan Acceleration and expansion of development Indonesia economic 2011-2025

Data were collected using secondary survey instruments through existing literature studies and policy reviews. Based on the results of analysis, recommendations were compiled for inputs in determining the development direction of development acceleration of Suramadu area following the concept of sustainable development. The secondary data needed in this study is explained in Table 1.

Table 1: Secondary Data Needs

\begin{tabular}{clll}
\hline No. & \multicolumn{1}{c}{ Data Source } & \multicolumn{1}{c}{ Data Needs } \\
\hline 1 & Coordinating Ministry for Economic Affairs & $\bullet$ & $\begin{array}{l}\text { Masterplan Acceleration and expansion of development } \\
\text { Indonesia economic 2011-2025 }\end{array}$ \\
\hline 2 & $\begin{array}{l}\text { Ministry of National Development } \\
\text { Planning/National Development Planning } \\
\text { Agency }\end{array}$ & $\bullet$ & National Medium-Term Development Plan of 2020-2024 \\
\hline 3 & Development Planning Agency of East Java & $\bullet$ & East Java Spatial Plan \\
& & $\bullet$ & Long-Term Development Plan of East Java \\
\hline 4 & Surabaya-Madura Regional Development & $\bullet$ & Agency Medium Term Strategic Plan of 2020-2024 \\
& Agency & $\bullet$ & $\begin{array}{l}\text { Master Plan for the Acceleration of Suramadu Regional } \\
\text { Development 2010-2024 }\end{array}$ \\
\hline 5 & Development Planning Agency of Surabaya & $\bullet$ & Surabaya Spatial Plan \\
\hline
\end{tabular}




\subsection{Analysis}

Descriptive analysis that was carried out in this research was the conformity analysis of SurabayaMadura Regional development agency strategic plan to the sustainable regional development concept. The conformity analysis aimed to explain the suitability of development planning policy with the sustainable development concept. Therefore, first, it was necessary to identify the programs contained in The Ministry/Institutions which in this case is Surabaya-Madura Regional Development Agency. The program produces several activities that will be carried out in order to achieve development targets. After identifying activities of the program, the next steps were determining activities that meet the rules of sustainable development theory through a checklist in the table column and conducting descriptive analysis to explain the suitability of the program to the concept of sustainable development. The results of conformity analysis were used to determine the development direction, so that the sustainable development targets can be achieved in the next five years.

\section{Results and Discussions}

\subsection{Suramadu Area Development of the Surrounding Territories}

In an archipelago, Suramadu area consists of several islands that are mutually affected by both the export and import activities between the islands and the needs of residents by its inhabitants, besides having its ecological functions that are important and need to be kept (Simsek et al., 2020). Based on the Master Plan for the Acceleration of Suramadu Regional Development 2010-2024, the development of Suramadu region is directed to be the strategic area of the economic field in Java-Bali region that serves as economic growth centers and have an economic scale with national and international competitiveness based on industry sector and national services, creative Economic Development Center, as well as one of the world's best tourist destination gateways, geared towards the development of food and beverage industry, textiles, transportation equipment, telematics, chemistry, alumina, and iron steel. One of the focuses of strategic area development in Java-Bali region is the development of Suramadu region as the economic mobilizer of the periphery area. Accelerating the development of strategic areas is conducted through the following strategies:

1. Development of the potential of Suramadu bridge foot of Madura side and the area of Suramadu bridge foot of Surabaya side, and a specific area in Madura Island.

2. Acceleration Strengthening of connectivity through the construction of access road industrial area in Madura to the container port.

Based on the Masterplan of acceleration and expansion of Indonesia Economic development 2011 2025 , the development of Suramadu area as a strategic area of other regions in national scope plays a role in supporting Java corridor for national industry and services. Industries and services developed include manufacturing industry, textile, transportation machinery, shipping, defense primary equipment, telematics, and metropolitan development of Jabodetabek. The city of Surabaya is in the Java corridor as one of the main infrastructure nodes in East Java with the international main port of Tanjung Perak and the main line to the outside corridor to the south of Surabaya, while eastwards to Madura Island. The existence of the international main port and main line in the city of Surabaya which is adjacent to Madura Island will have an impact on the economy if the development of Suramadu strategic area is implemented well.

When it is reviewed from the ecological function, both areas in Surabaya and Madura have similarities such as directly adjacent to the waters of Madura Strait, so that in Surabaya and Madura region there is a coastal area. Coastal areas have always received impact, both from activities in the upstream and in the coastal areas themselves. Therefore, the development of Surabaya-Madura region should pay attention to the aspects of environmental conservation so that activities in both areas do not adversely affect the waters of Madura Strait and coastal areas in the vicinity of potential as a provider of fishery resources, tourism, sea transportation, etc. 


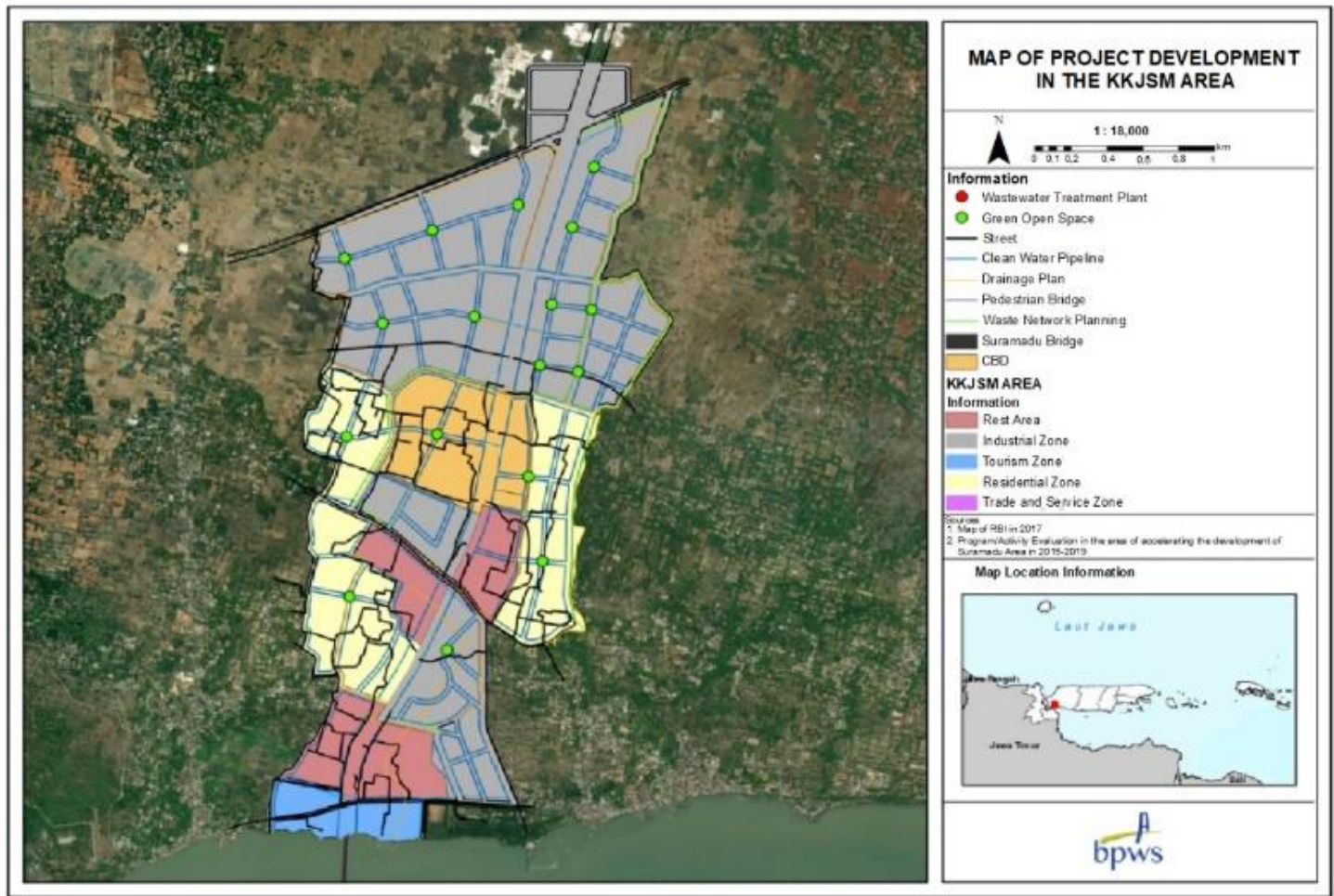

Figure 3. Development of Strategic area Project Suramadu, access toll road Suramadu and the port of container Tanjung Bulu Pandan-(Perpres 27/2008 Article 12 letter B, C, D), according to the reference Space (spatial Unit), Master Plan for the Acceleration of Suramadu Regional Development 2010-2024

\subsection{The Concept of Sustainable Development}

Sustainable development is a social construction with the rules of decision-making based on values related to current and future development, which must be understood in the context of a dynamic environment, inseparable from society (De Zeeuw et al., 2010; Eustachio et al., 2019). Sustainable development conducts development to meet current needs without compromising the need for future generations with an emphasis on environmental support, achievement of social justice, sustainable economics (Janković Šoja et al., 2016). The Followings are the policies and research findings obtained in supporting sustainable development in the Surabaya-Madura Region.

\subsubsection{Environmental development}

Environmental development is the achievement of sustainable natural resources and environmental management as the buffer of the whole life (Opon \& Henry, 2019; Ramos, 2009). Environmentally sustainable means keeping the environment comfortable and safe through zero-emission (Feola et al., 2020; Shen et al., 2013). In environmental development, the main aspects that need to be considered are water quality, air quality, environmental management, and biodiversity (Kono et al., 2018; Torabi Moghadam et al., 2017). The development concept of Surabaya-Madura region that supports environmental development is shown in the provision of clean water network infrastructure, and wastewater and waste management infrastructure.

The Surabaya City Regulation No. 12/2014 on spatial planning of the city of Surabaya shows that environmental development is directed at optimizing the utilization of surface water resources and other water sources; increasing water catchment through optimization of the reservoir function for water tourism, environmental arrangement, conservation; managing the city's domestic waste to reduce the environmental pollution level, through the provision of centralized wastewater treatment plant (WWTP) installation and integrated communal WWTP; and optimizing the function of landfill and facility of hygiene 
infrastructure and develop the environmentally friendly waste technology. Madura Island regions, especially those located on the north coast, need to support water resources development. In 2019, clean water treatment capacity available in Madura Island reached 1,300 liters/sec while water resources potential of 33,500 liters/second. In 2019, the fulfilment of the needs of drinking water in Madura Island still reached $20.93 \%$ of the total population, such as: Users of local water supply utilities by $12.98 \%$, Drinking Water User Population Association by $0.78 \%$, users of WSLIC (Water Sanitation for Low-Income Communities) by $1.7 \%$, and users of shallow well by $5.5 \%$.

When associated with the program at the strategic planning document of Surabaya Madura Regional Development Agency, in the development program of Suramadu Strategic area, there are infrastructure development activities of Madura area infrastructure development of 14 priority tourism destinations and development of 6 strategic industry priorities. Thus, infrastructure development needs to be prepared for service activities in industrial areas. The research results show that some SPAM has been functioning properly while others are still not able to function optimally. Then, clean water network for the preparation of industrial area especially in Suramadu area has met the standard of Permenperin 35/2010 on industrial Area technical guidelines stating that the minimum standard of clean water in an industrial area is $0.55 \mathrm{~L} / \mathrm{sec} / \mathrm{Ha}$. This was obtained by looking at the suitability between potential land area development of drinking water supply system by Surabaya-Madura Regional Development Agency and the preparation of industrial areas, especially in the working area of Surabaya Madura Regional Development Agency with the amount of clean water needed to support industrial activities in the Surabaya-Madura region.

Table 2: Estimation of the need for clean water network for industrial Area plan in Madura

\begin{tabular}{|l|l|l|l|}
\hline $\begin{array}{c}\text { Clean water supplies Industrial } \\
\text { Area }\end{array}$ & $\begin{array}{c}\text { Industrial Area around } \\
\text { the foot of Suramadu } \\
\text { Bridge }\end{array}$ & $\begin{array}{c}\text { Industrial Area of Madura } \\
\text { Special Area }\end{array}$ & Unit \\
\hline Land & 600 & 600 & $\mathrm{Ha}$ \\
\hline Standard Requirements & 0.55 & 0.55 & $\mathrm{~L} / \mathrm{sec} / \mathrm{Ha}$ \\
\hline Total needs & 1090.90 & $1,090,90$ & $\mathrm{~L}$ \\
\hline Source: Analysis result, 2019 & & & \\
\hline
\end{tabular}

The fulfilment of clean water needs can be served by PDAM, however for optimized result, each industrial area that is close to water resources, such as rivers, can make water treatment plant itself. Besides, the infrastructure that must be prepared to serve the Development Plan 6 Strategic Industries is the provision wastewater treatment plant (WWTP) installation so that it can be done for waste management before it is disposed to drains, rivers, and seas so as not to cause environmental pollution. The provision of waste facilities is also required by providing a waste system to serve industrial area by utilizing environmentally friendly technology.

\subsubsection{Economic development}

Sustainable economics means a development activity should be able to generate economic growth, capital preservation, resource usage, and investments (Nogués et al., 2019). Economic sustainability also means maintaining stable economic growth by restructuring productive systems to conserve resources and energy (Haider et al., 2018; Horsley et al., 2015).

Economic development in the Suramadu region is carried out through the development of economic growth centers based on the potential and superiority of each region, both existing and potentially to be developed as well as strengthened by the regional development policy document such as National Medium-Term Development Plan, National Spatial Plan, Long-Term Development Plan of East Java, Local Spatial Plan, Surabaya and Madura Spatial Plan. The development of the economic growth center is accompanied by strengthening connectivity cross growth centers and between economic growth center and the location of economic activities as well as infrastructure and its supporting human resources (Kempenaar et al., 2016). The development of Suramadu region also needs to be synchronized with the surrounding area, through the integration of Growth Center development in Suramadu region with the growth area in Java Island, integration of urban system development in Suramadu region with the urban system in Java Island, and integration of economic and transportation system in Suramadu region with the surrounding region. 
The concept of economic development to support the accelerating development of a strategic region of Surabaya-Madura is conducted through the development of Economic growth center of Madura. This is done with the development of core regional and local economic clusters so as it can create the development of Suramadu economic corridor in network connectivity cross-district and regional East Java.

1) The core region consists of:

- The Region around the foot of Suramadu Bridge is Madura as the gateway and marketingorientation of Madura.

- Madura Special Region as a Madura main port's support that is outward-oriented in the National logistics system.

2) Flagship cluster consists of:

- Development of core region is a marketing-oriented which requires the support of the center of production and processing. Thus, the development of new growth center of Madura must be done thoroughly, with attention to the upstream and downstream sectors.

- Development of economic clusters as upstream and downstream link of Madura economic development aims to increase productivity and added value of natural resources management through the expansion and creation of chain activities from upstream to downstream sustainably serve the industrial area by utilizing environmentally friendly technology.

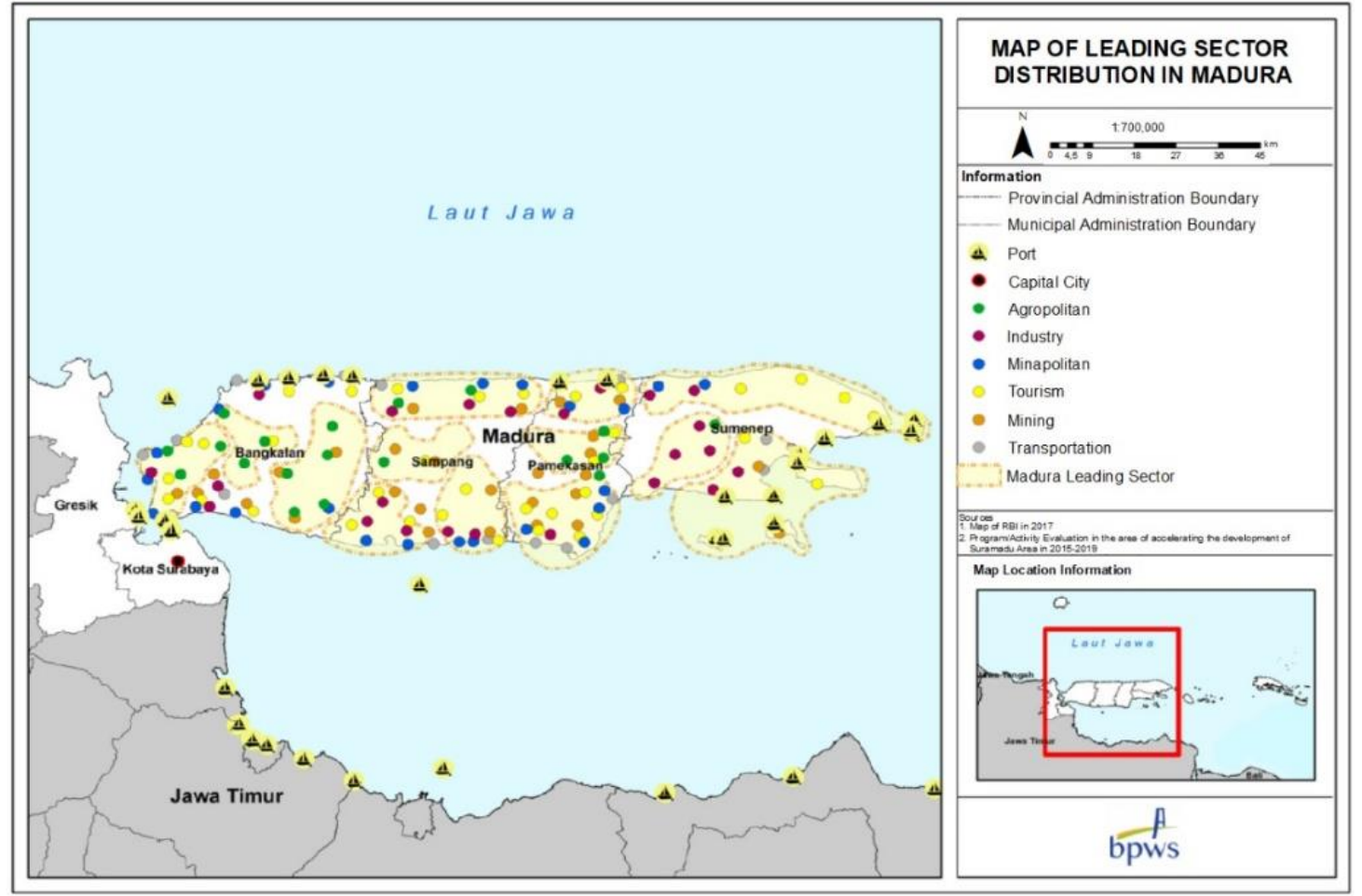

Figure 4. Division of Madura flagship cluster Source, 2019

The development of the core region (The Region around the foot of Suramadu Bridge and Madura Special Region) is part of the national strategic region of Gerbangkertosusila and the strategic region of East Java province for economic development and the strict control area of East Java province. Therefore, the development of the two regions, besides having to pay attention to its strategic value, pays attention to its functions in the national and regional scope. In the regional sphere, region development is realized through the development of urban centers as the center of marketing and distribution products to other regions supported by the connectivity of urban systems-its supporting areas (hinterland) (Jain \& Tiwari, 2017). Meanwhile, the scope of national development is realized through the development of the main transport nodes. 
On the other hand, the development of Madura's flagship cluster is done by strengthening the production centers (agriculture, fisheries, etc.) which are based on local potentials and strengthening the market through the empowerment of cultivation and agribusiness/business activities upstream to the downstream, institutional system development and related system of the villages (Urban-Rural linkage). The interconnectedness system aims to develop mutually beneficial interactions between cluster centers and production centers that can provide added value for production so that it can spur regional development, increase productivity and quality of superior products, improve the income and welfare of people in the hinterland area, development of the center of regional economic growth that will eventually suppress the pace of urbanization. Cluster development in the Madura region focuses on strategic sectors of agriculture, marine and fisheries, tourism and industry/trade services.

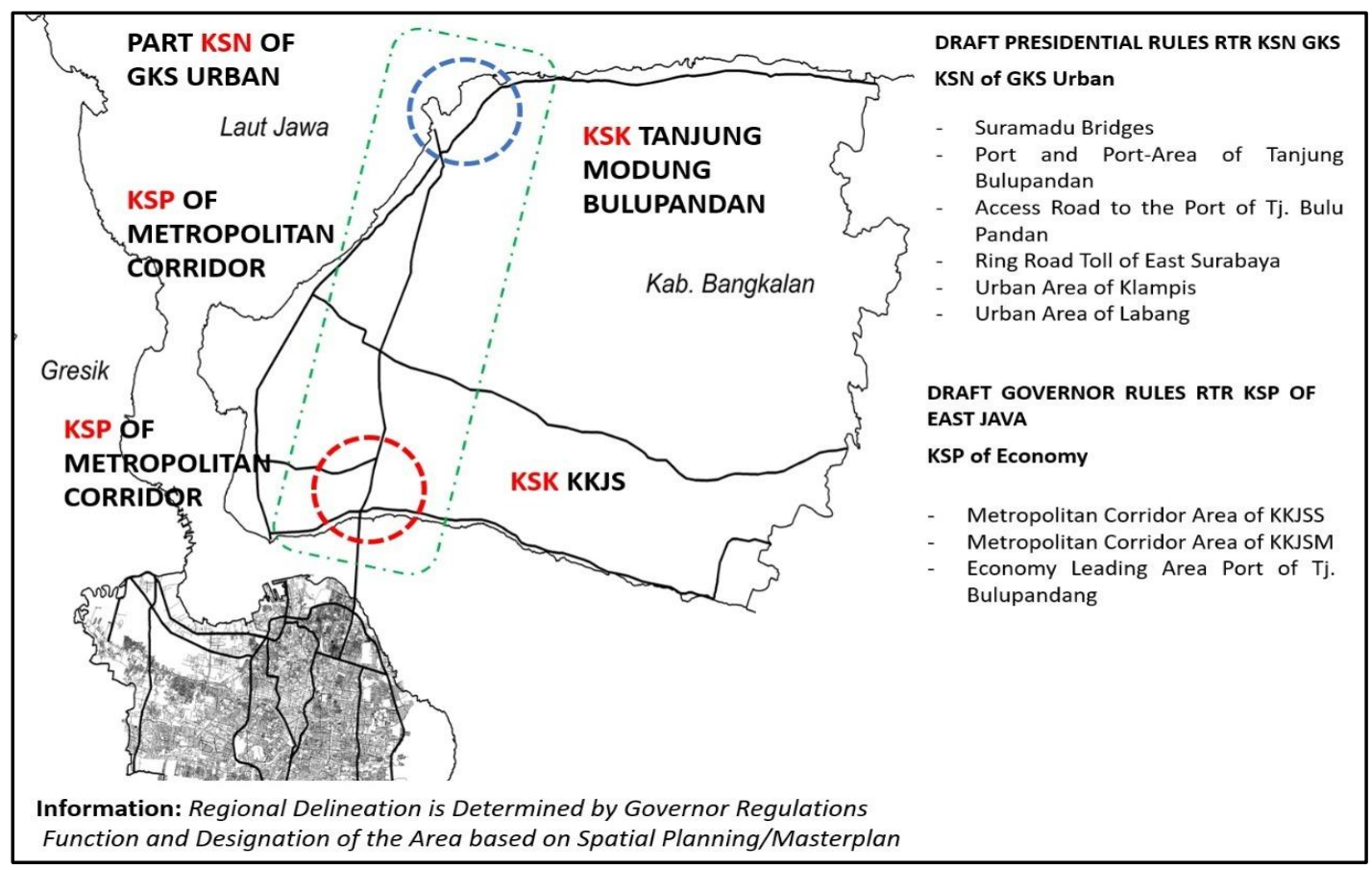

Figure 5. Suramadu region position in spatial planning, adopted from the master plan of Surabaya-Madura Regional Development Agency 2010-2024 and strategic planning of Surabaya-Madura Regional Development Agency 2015-2019

Economic development through growth centers in Madura is expected to contribute to the economic stability in Madura by using efficient human resources and investment. When associated with programs at the Strategic Planning of BPWS, aspects of economic development have been accommodated in the management support program and the implementation of other technical tasks through the development of professional internal HR to manage and build the strategic region of Suramadu. The Suramadu's Strategic Region Development Program in supporting aspects of economic development has been accommodated through the activities of investment in the area and development of Suramadu's human resources, the infrastructure development of Madura region, infrastructure development of 14 priority tourism destinations, and infrastructure development of 6 strategic industries in Madura. The implementation of investment activities, human resources, and infrastructure development will provide added value to support the economy in the strategic area of the Surabaya-Madura region and make an impact on the surrounding area especially the suburbs (coastal Strait of Madura).

\subsubsection{Social development}

The Social aspect is an attribute that does not belong to an individual, but it belongs to the community that reflects how much society is ready to face its problems and seeks solutions that drive sustainability (Saldaña-Márquez et al., 2018). Social development is the achievement of fair and equal quality human rights to improve welfare for the whole community (Harun, n.d.). Social sustainability means ensuring 
social justice in the distribution of wealth and social services, therefore development must be evenly and perceived by all parties (Hák et al., 2016).

Suramadu Bridge Development Policy is an effort to improve the unity of Madura Island with Java Island and encourage economic development towards Madura Island in order not avoid the development gap between Madura and East Jawa, i.e. the economic condition of Madura Island is quite low compared to other districts in East Java province. Madura economic growth is directed in a framework of development that is based on the balance cross regions, i.e. the development of growth centers where growing areas are continuously improved while relatively less developed areas continue to be driven by the infrastructure development to strengthen national, regional and local connectivity systems. Strengthening the connectivity system will be able to improve the flow of goods, services, and information, lower the cost of logistics, reduce the high economic costs, create equitable access throughout the region and realize the synergy between the centers of economic growth.

Social development is realized through the easiness of accessibility with the Suramadu bridge which unites the economic development region of Java and Madura in one corridor. The strengthening of the Suramadu region infrastructure is carried out integrated into one system, i.e. transport vertices (ports, terminals, airports, distribution centers, and warehousing areas) are integrated into the network of infrastructure that is effectively and efficiently connected. Strengthening the connectivity of supporting infrastructure is done by linking among the centers of economic activities (production, processing, and marketing) in the cluster/region, cross the centers of the cluster economic activities/areas to the service centers and outlet doors that will impact the smooth flow of goods and the effectiveness of economic activities.

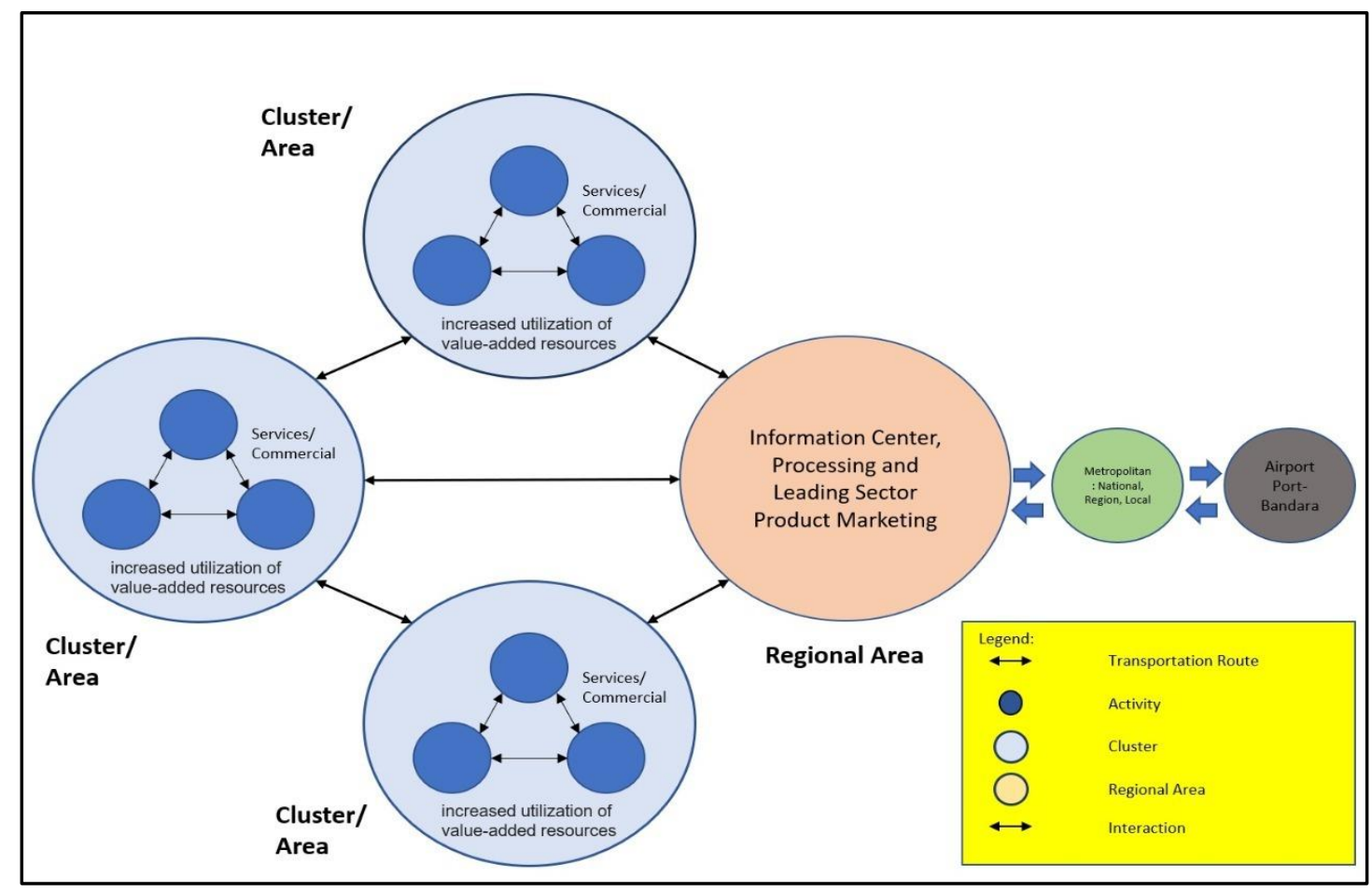

Figure 6. The concept of development of Madura cluster, Adopted from the master plan of Surabaya-Madura Regional Development Agency 2010-2024

The development of the superior economic clusters in Madura is supported by the infrastructure development that supports the production, processing, and marketing activities. The development of infrastructure and facilities depends on the category, typology, and role of the cluster to be developed. Infrastructure and cluster facilities development is intended to provide coaching, enhancement, and added value concerning internal and external cluster activities. Trading activities/services to support 
the marketing of excellent products/commodities (external) and small-medium industries and trade/support services activities of production processing (internal). The development of such infrastructure and cluster facilities needs to be supported by inter-cluster transport network connectivity and in clusters.

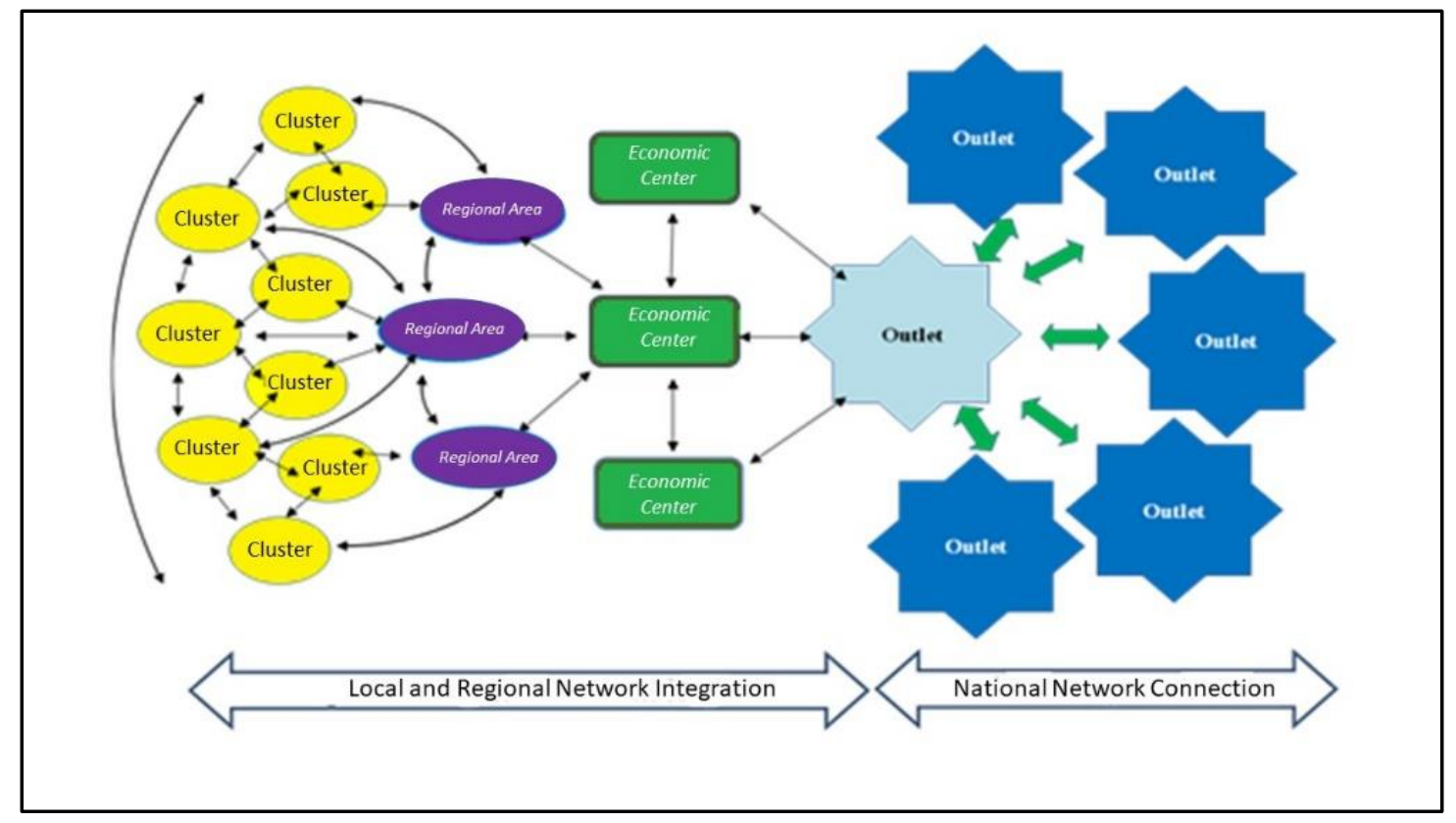

Figure 7. The Network of National Connectivity Systems, adopted from the master plan Surabaya-Madura Regional Development Agency 2010-2024

When associated with programs at the Strategic Planning of Surabaya-Madura Regional Development Agency, the implementation of the program needs to be based on Social development aspect that can be realized through the easiness of accessibility of the community in utilizing educational facilities, health facilities and other public facilities so that it is expected to create a quality society. The Suramadu's Strategic Region Development Program in supporting aspects of social development has been accommodated through the activities of investment in the region and development of Suramadu's human resources, the infrastructure development of Madura region, infrastructure development of 14 priority tourism destinations, and infrastructure development of 6 strategic industries in Madura. Implementation of investment activities and human resources and infrastructure development needs to be focused on the unconnected well regions so that the development of community infrastructure can have the easiness to move towards fulfilling the daily needs. The implementation of support programs and other technical management also needs to be adapted to the aspects of social development where it needs the improvement of internal HR quality to provide professional human resources so that they can perform their job well.

\subsection{Conformity analysis of Surabaya-Madura Regional Development Agency Strategic Plan to the Concept of Sustainable Development}

The conformity analysis of Surabaya-Madura regional development agency strategic plan on the sustainable regional development concept is conducted by comparing the sustainable regional development concept consisting of social development, economic, and environmental toward programs on Surabaya-Madura Regional Development Agency strategic plan; so that, it can get the development 
direction for the implementation of these programs that are in in line with the sustainable regional development concept.

Table 3: Conformity analysis of the Strategic Plan Programs to Sustainable Development Concept

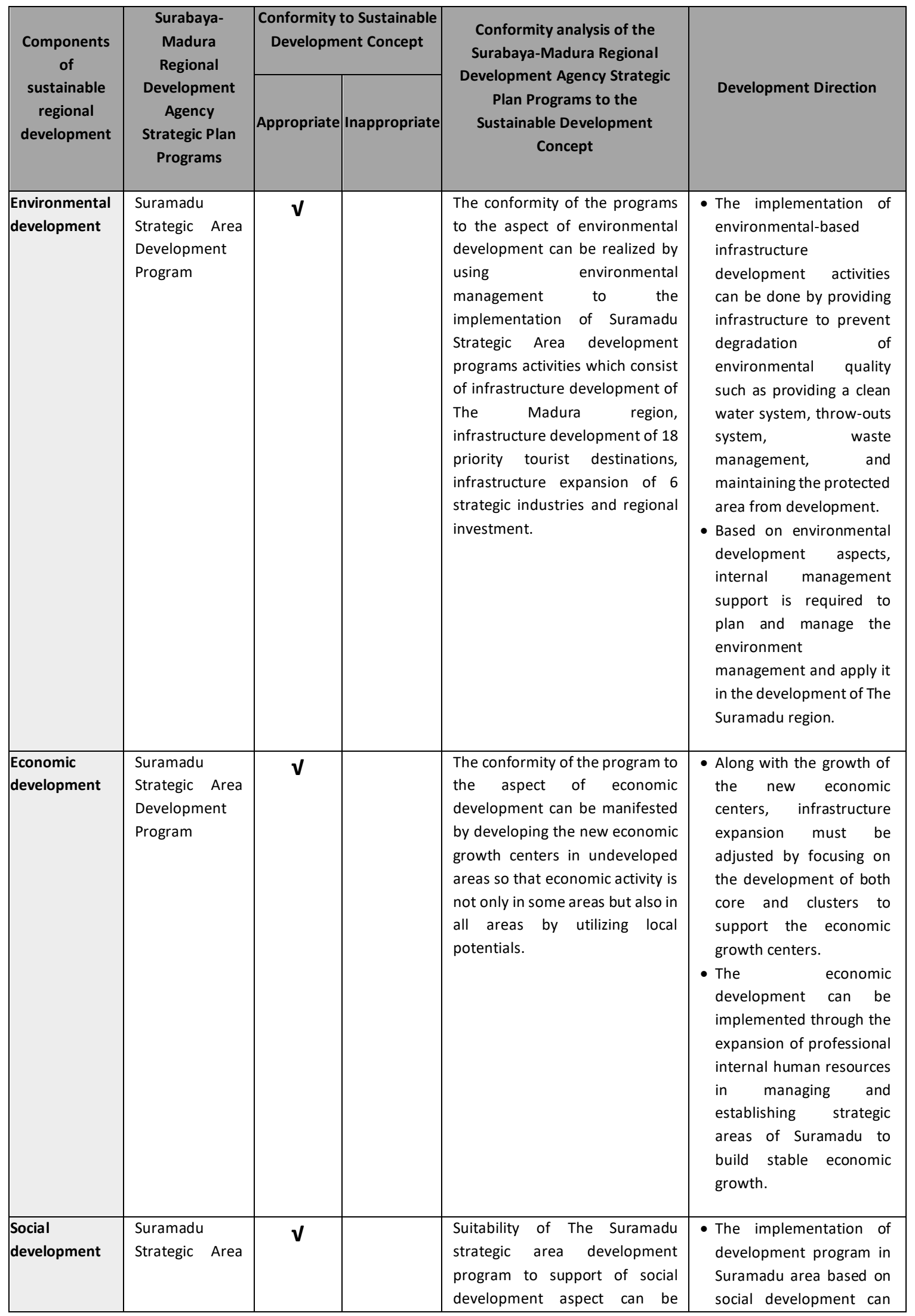




\begin{tabular}{|c|c|c|c|c|c|}
\hline \multirow{2}{*}{$\begin{array}{l}\text { Components } \\
\text { of } \\
\text { sustainable } \\
\text { regional } \\
\text { development }\end{array}$} & \multirow{2}{*}{$\begin{array}{l}\text { Surabaya- } \\
\text { Madura } \\
\text { Regional } \\
\text { Development } \\
\text { Agency } \\
\text { Strategic Plan } \\
\text { Programs }\end{array}$} & \multicolumn{2}{|c|}{$\begin{array}{l}\text { Conformity to Sustainable } \\
\text { Development Concept }\end{array}$} & \multirow{2}{*}{$\begin{array}{l}\text { Conformity analysis of the } \\
\text { Surabaya-Madura Regional } \\
\text { Development Agency Strategic } \\
\text { Plan Programs to the } \\
\text { Sustainable Development } \\
\text { Concept }\end{array}$} & \multirow[b]{2}{*}{ Development Direction } \\
\hline & & Appropriate & Inappropriate & & \\
\hline & $\begin{array}{l}\text { Development } \\
\text { Program }\end{array}$ & & & $\begin{array}{l}\text { manifested with the regional } \\
\text { investment and Suramadu } \\
\text { human resources development, } \\
\text { infrastructure development in } \\
\text { the Madura region, } 14 \text { priority } \\
\text { tourism destinations } \\
\text { infrastructure development, } \\
\text { expansion of } 6 \text { strategic } \\
\text { industries in Madura. The } \\
\text { practice of undertaking regional } \\
\text { investment activities and human } \\
\text { resources along infrastructure } \\
\text { development needs to be } \\
\text { focused on areas that did not } \\
\text { connect well; thus, with the } \\
\text { infrastructure development, } \\
\text { people can have the ease to } \\
\text { move towards fulfilling the daily } \\
\text { needs. }\end{array}$ & $\begin{array}{l}\text { be implemented by } \\
\text { developing the } \\
\text { accessibility in utilizing } \\
\text { public facilities. It can be } \\
\text { expected to increase the } \\
\text { life quality of the } \\
\text { community through that } \\
\text { ease of accessibility to } \\
\text { facilities of educational, } \\
\text { recreational facilities, } \\
\text { health facilities, etc. } \\
\text { Based on the social } \\
\text { development aspect, } \\
\text { internal HR support is } \\
\text { required to plan and } \\
\text { manage the development } \\
\text { that leads to equitable } \\
\text { development that can be } \\
\text { felt by the whole society. } \\
\text { The practice of } \\
\text { communication } \\
\text { management activities, } \\
\text { public information, risk } \\
\text { management, and area } \\
\text { control is conducted } \\
\text { based on the social } \\
\text { development aspects that } \\
\text { prioritize the community } \\
\text { interest above the } \\
\text { particularistic groups. }\end{array}$ \\
\hline
\end{tabular}

Source: Analysis results, 2020

\section{Conclusions}

In the environmental development component, the results of the study show that there has been a policy direction that leads to environmental sustainability such as the provision of clean water network system, the final processing place (TPA) optimization to resolve the waste problems, the manufacture of wastewater management installations and environmentally friendly technology. Therefore, it is necessary to optimize the strengthening and integration of policies or programs by both the provincial government and local governments (Curtis \& Scheurer, 2010). The recommendation based on this research has required the implementations of detailed plan of facility and infrastructure development that supports environmental sustainability and can accommodate policies regarding the priority of tourism destinations infrastructure development and strategic industries. This means the detailed plan must contain the readiness of infrastructure to fulfill the needs of the region when the strategic industry and priority tourist destination are developed.

In the components of economic development, the results of the study show that there has been a policy direction that leads to economic sustainability by developing the new economic growth centers in some regions that are divided into core and prime clusters according to the regional potential. The optimization of local potentials in each region is expected to provide the value of production and build mutually beneficial interactions among the region so that the maintenance of capital can be implemented 
by the community. To strengthen the realization of the policy, there needs to be a policy integration by the central, provincial and Regency/city governments considering the development of core areas is a part of the national strategic urban area of Gerbangkertosusila and the strategic area of East Java province for economic development and strict control areas of East Java province. Based on this research, it is necessary to have a detailed plan in realizing the policy of development of economic growth centers in the core and the prime clusters such as developing models of production processing, marketing and promotion and developing regional facilities such as public social facilities, regional terminals, regional warehousing areas, regional trade in the provincial strategic area.

In the social development component, the results of the study show there has been a policy direction that leads to social sustainability such as strengthening the Suramadu regions connectivity infrastructure that carried out integrated with one system, where the transport nodes (ports, terminals, airports, distribution centers, and warehousing areas) were integrated into the infrastructure network that was effectively and efficiently connected. Therefore, there needs to strengthening the optimization and integration of policies or programs either by the central, provincial, or local governments. This research recommends a detailed plan which contains the regional connectivity development system from the production area to the marketing in the regions, the development of a network of railways to improve the region accessibility to the port as well as the development of other supporting infrastructure by linking the centers of economic activities (production, processing, and marketing) in clusters/regions, interregional/interactivities of the cluster economic centers to service centers and outlet doors. Therefore, this will impact the flow of goods and the effectiveness of economic activities.

\section{Acknowledgments}

We would like to express our gratitude to God Almighty for enabling us to complete this research paper on "A Review of Suramadu Regional Development Acceleration Towards Sustainable Development Concepts." Our greatest gratitude goes to all Agency Officials of the Suramadu Regional Development Agency for providing the opportunity and useful data. Gratitude is also due to Wignyo Adiyoso as Department Head of Center for Development of Education and Training of Planners of Bappenas for sharing the earlier drafts of the paper.

\section{References}

Curtis, C., \& Scheurer, J. (2010). Planning for sustainable accessibility: Developing tools to aid discussion and decision-making. Progress in Planning, 74(2), 53-106. https://doi.org/10.1016/j.progress.2010.05.001

De Zeeuw, F., Franzen, A., Aalbers, K., Van Hal, A., \& Dulski, B. (2010). Designing the Future. Sustainability, 2(4), 902-918. https://doi.org/10.3390/su2040902

Eustachio, J. H. P. P., Caldana, A. C. F., Liboni, L. B., \& Martinelli, D. P. (2019). Systemic indicator of sustainable development: Proposal and application of a framework. Journal of Cleaner Production, 241, 118383. https://doi.org/10.1016/j.jclepro.2019.118383

Feola, G., Suzunaga, J., Soler, J., \& Wilson, A. (2020). Peri-urban agriculture as quiet sustainability: Challenging the urban development discourse in Sogamoso, Colombia. Journal of Rural Studies, S0743016719310721. https://doi.org/10.1016/j.jrurstud.2020.04.032

Haider, H., Hewage, K., Umer, A., Ruparathna, R., Chhipi-Shrestha, G., Culver, K., Holland, M., Kay, J., \& Sadiq, R. (2018). Sustainability assessment framework for small-sized urban neighbourhoods: An application of fuzzy synthetic evaluation. Sustainable Cities and Society, 36, 21-32. https://doi.org/10.1016/j.scs.2017.09.031

Hák, T., Janoušková, S., \& Moldan, B. (2016). Sustainable Development Goals: A need for relevant indicators. Ecological Indicators, 60, 565-573. https://doi.org/10.1016/j.ecolind.2015.08.003

Harun, U. R. (n.d.). MODEL PERENCANAAN PENGEMBANGAN WILAYAH KEPULAUAN NUSA TENGGARA. Jurnal Perencanaan Wilayah dan Kota, 14.

He, Z., Jiang, L., Wang, Z., Zeng, R., Xu, D., \& Liu, J. (2019). The emergy analysis of southern China agroecosystem and its relation with its regional sustainable development. Global Ecology and Conservation, 20, e00721. https://doi.org/10.1016/j.gecco.2019.e00721

Heidenreich, M. (2003). Regional Inequalities in the Enlarged Europe. Journal of European Social Policy, 13(4), 313-333. https://doi.org/10.1177/09589287030134001 
Horsley, J., Prout, S., Tonts, M., \& Ali, S. H. (2015). Sustainable livelihoods and indicators for regional development in mining economies. The Extractive Industries and Society, 2(2), 368-380. https://doi.org/10.1016/j.exis.2014.12.001

Jain, D., \& Tiwari, G. (2017). Sustainable mobility indicators for Indian cities: Selection methodology and application. Ecological Indicators, 79, 310-322. https://doi.org/10.1016/j.ecolind.2017.03.059

Janković Šoja, S., Anokić, A., Bucalo Jelić, D., \& Maletić, R. (2016). Ranking EU Countries According to Their Level of Success in Achieving the Objectives of the Sustainable Development Strategy. Sustainability, 8(4), 306. https://doi.org/10.3390/su8040306

Kempenaar, A., Westerink, J., van Lierop, M., Brinkhuijsen, M., \& van den Brink, A. (2016). “Design makes you understand"-Mapping the contributions of designing to regional planning and development. Landscape and Urban Planning, 149, 20-30. https://doi.org/10.1016/j.landurbplan.2016.01.002

Kono, J., Ostermeyer, Y., \& Wallbaum, H. (2018). Investigation of regional conditions and sustainability indicators for sustainable product development of building materials. Journal of Cleaner Production, 196, 1356-1364. https://doi.org/10.1016/j.jclepro.2018.06.057

Kroll, C., \& Zipperer, V. (2020). Sustainable Development and Populism. Ecological Economics, 176, 106723. https://doi.org/10.1016/j.ecolecon.2020.106723

Munda, G., \& Saisana, M. (2011). Methodological Considerations on Regional Sustainability Assessment Based on Multicriteria and Sensitivity Analysis. Regional Studies, 45(2), 261-276. https://doi.org/10.1080/00343401003713316

Nogués, S., González-González, E., \& Cordera, R. (2019). Planning regional sustainability: An index-based framework to assess spatial plans. Application to the region of Cantabria (Spain). Journal of Cleaner Production, 225, 510-523. https://doi.org/10.1016/j.jclepro.2019.03.328

Opon, J., \& Henry, M. (2019). An indicator framework for quantifying the sustainability of concrete materials from the perspectives of global sustainable development. Journal of Cleaner Production, 218, 718-737. https://doi.org/10.1016/j.jclepro.2019.01.220

Ramos, T. B. (2009). Development of regional sustainability indicators and the role of academia in this process: The Portuguese practice. Journal of Cleaner Production, 17(12), 1101-1115. https://doi.org/10.1016/j.jclepro.2009.02.024

Saldaña-Márquez, H., Gómez-Soberón, J. M., Arredondo-Rea, S. P., Gámez-García, D. C., \& Corral-Higuera, R. (2018). Sustainable social housing: The comparison of the Mexican funding program for housing solutions and building sustainability rating systems. Building and Environment, 133, 103122. https://doi.org/10.1016/j.buildenv.2018.02.017

Shen, L., Kyllo, J., \& Guo, X. (2013). An Integrated Model Based on a Hierarchical Indices System for Monitoring and Evaluating Urban Sustainability. Sustainability, 5(2), 524-559. https://doi.org/10.3390/su5020524

Silva, J. da, Fernandes, V., Limont, M., \& Rauen, W. B. (2020). Sustainable development assessment from a capitals perspective: Analytical structure and indicator selection criteria. Journal of Environmental Management, 260, 110147. https://doi.org/10.1016/j.jenvman.2020.110147

Simsek, Y., Santika, W. G., Anisuzzaman, M., Urmee, T., Bahri, P. A., \& Escobar, R. (2020). An analysis of additional energy requirement to meet the sustainable development goals. Journal of Cleaner Production, 272, 122646. https://doi.org/10.1016/j.jclepro.2020.122646

Szopik-Depczyńska, K., Cheba, K., Bąk, I., Stajniak, M., Simboli, A., \& Ioppolo, G. (2018). The study of relationship in a hierarchical structure of EU sustainable development indicators. Ecological Indicators, 90, 120-131. https://doi.org/10.1016/j.ecolind.2018.03.002

Torabi Moghadam, S., Delmastro, C., Corgnati, S. P., \& Lombardi, P. (2017). Urban energy planning procedure for sustainable development in the built environment: A review of available spatial approaches. Journal of Cleaner Production, 165, 811-827. https://doi.org/10.1016/j.jclepro.2017.07.142

Program Evaluation Report on Monitoring and Evaluation of the 2019 Madura Regional Development Acceleration Program

Presidential Regulation No. 23/2009 concerning Amendment to Presidential Regulation No. 27/2008 concerning Badan Pengembangan Wilayah Surabaya - Madura

Presidential Regulation Number 2 the Year 2015 concerning the National Medium Term Development Plan (RPJMN) for 2015 - 2019 
Master Plan for the Acceleration of Suramadu Regional Development (Rencana Induk Percepatan Pengembangan Wilayah Suramadu (RIP2WS) 2010-2024

Strategic Plan of Badan Pengembangan Wilayah Surabaya-Madura 2015-2019 Jawa Timur in figures 2020 Gross Regional Domestic Product in East Java Province according to Business Field 2015-2019 